\title{
DASAR NEGARA DAN TAQIYYAH POLITIK PKS
}

\author{
Abu Rokhmad \\ IAIN Walisongo Semarang \\ e-mail: abu_rokhmad@yahoo.com
}

\begin{abstract}
This article studied about the relationship between Partai Keadilan Sejahtera (PKS/the Prosperous Justice Party) and Pancasila as the state's philosophy. PKS didn't have the experience of the struggle of Indonesian independence and the difficult period of the Pancasila formulation. PKS was born after Pancasila convinced as the national agreement. The political attitude of PKS to Pancasila as the state's philosophy is still indistinct. PKS viewed as political party that hide their truly intent: between receiving Pancasila and implementing islamic shari'ah. The aspiration of implementing islamic shari'ah has been concealing in vision and mission as well as in the heart of PKS's cadres. The aspiration will be done by peaceful and constitutional ways.

Artikel ini mengkaji relasi Partai Keadilan Sejahtera (PKS) dengan Pancasila sebagai dasar negara. PKS tidak mengalami perjuangan meraih kemerdekaan dan masa-masa sulit perumusan Pancasila. PKS lahir setelah Pancasila diyakini sebagai perjanjian suci kebangsaan. Sikap PKS terhadap Pancasila sebagai dasar negara masih mengambang. Ia dipandang menyembunyikan maksud hati yang sebenarnya: antara menerima Pancasila atau menegakkan syariat Islam. Cita-cita menegakkan syariat Islam tersimpan dalam visi, misi dan hati para kader PKS, yang akan dilakukan secara damai dan konstitusional.
\end{abstract}

Keywords: Pancasila, dasar negara, PKS, taqiyyah politik 


\section{A. Pendahuluan}

Selama Orde Baru, Pancasila berdiri kokoh sebagai dasar dan ideologi negara. Pancasila berkibar karena dukungan kekuasaan. Masyarakat didoktrin dan dipaksa mengakui Pancasila sebagai asas tunggal melalui kegiatan penataran P4 (Pedoman Penghayatan dan Penghayatan Pancasila) yang diselenggarakan secara massal dan sistematis. Kesetiaan kepada Pancasila diukur dari hafalan dan penguasaan butir-butir sila dalam Pancasila.

Pancasila ditafsirkan sesuai kepentingan Orde Baru. Segala kegiatan yang patut diduga dapat mengancam Pancasila dikriminalisasi oleh negara lewat penerapan UU No. 11/PNPS/1963 tentang Pemberantasan Kegiatan Subversi. Umat Islam sangat merasakan tindakan represif pemerintahan Soeharto, apalagi rezim tersebut masih menganggap Islam merupakan ancaman bagi Pancasila. ${ }^{1}$

Era reformasi membuat segalanya berubah. Demokrasi menjadi ruh reformasi dimana kebebasan dan keterbukaan dapat dinikmati seluruh komponen bangsa. Umat Islam juga bebas menyuarakan aspirasinya, termasuk dalam menyikapi Pancasila sebagai dasar negara. Muslim garis keras (hardliners) lahir bersamaan dengan momentum reformasi ini. ${ }^{2}$ Sejak era itu pula, popularitas Pancasila jatuh terpuruk. Wibawa dan keampuhan Pancasila kian pudar. ${ }^{3}$

Pancasila yang telah diperjuangkan oleh para bapak pendiri bangsa (the founding fathers) dengan jiwa dan air mata, kini tak lagi dijaga dan dihormati sebagaimana mestinya. Sebagian umat Muslim — secara terang-terangan maupun tersembunyi- bahkan hendak mengganti Pancasila dengan dasar agama. Mereka memang membaca Pancasila, tapi berbunyi lain: Allah SWT tujuanku, alQur'an konstitusiku, Muhammad SAW imamku, jihad jalanku dan syahid puncak impianku. ${ }^{4}$

\footnotetext{
${ }^{1}$ Anggapan ini didasarkan pada sejarah bahwa pada Sidang BPUPKI dan Konstituante 1957, kalangan Islam menolak Pancasila sebagai dasar negara. NU baru menerima Pancasila sebagai asas tunggal pada 1983, sedangkan Muhammadiyah pada 1985. Baca M. 'Ali Haidar, Nahdlatul Ulama dan Islam di Indonesia: Pendekatan Fikih dalam Politik, (Jakarta: Gramedia, 1998); Lukman Harun, Muhammadiyah dan Asas Pancasila, (Jakarta: Pustaka Panjimas, 1986).

2Baca Arskal Salim dan Azyumardi Azra, "Introduction: The State and Shari'a in the Perspective of Indonesian Legal Politics," dalam Sharia and Politics in Modern Indonesia, Arskal Salim and Azyumardi Azra (ed.), (Singapore: Institute of Southeast Asian Studies, 2003).

3Ahmad Syafii Maarif, "Saat Pancasila Tak Lagi Bertaji," Kompas, 10 April 2012.

4Masdar Farid Mas'udi, “Dulu P-4, kini 4-P,” Kompas, 5 April 2012.
} 
Menurut Ansyad Mbai, terdapat lima tipologi Islam radikal yang hendak memisahkan diri dari Indonesia atau mengganti Pancasila dengan negara Islam, seperti HTI (Hizbut Tahrir Indonesia), MMI (Majelis Mujahidin Indonesia), NII (Negara Islam Indonesia), JI (Jama'ah Islamiyyah) dan lain-lain. ${ }^{5}$ HTI misalnya, dalam berbagai pemikiran dan aksinya selalu menjadikan khilāfah islāmiyyah atau formalisasi syariat Islam sebagai solusi dari semua persoalan yang dihadapi bangsa. ${ }^{6}$ Ide khiläfah islämiyyah sangat berbeda dan bertentangan dengan ideologi Pancasila.

Meskipun mayoritas umat Islam (diwakili NU dan Muhammadiyah) menerima Pancasila sebagai dasar negara, tetapi masih banyak kelompok Islam yang belum atau tidak menerimanya. Bahkan partai politik Islam yang lahir dari rahim reformasi, Partai Keadilan Sejahtera (PKS) misalnya, visi partai dan sebagian kadernya diduga masih "menduakan" Pancasila.

Dhume melukiskan PKS sebagai "gerakan gradual dan evolusioner untuk menegakkan negara Islam di Indonesia." Bahkan ia menyamakan cita-cita politik PKS dengan JI. Partai hanyalah kedok konstitusional semata. ${ }^{7}$ Steele mengingatkan publik untuk mengawasi agenda-agenda tersembunyi PKS yang bermain melalui isu-isu anti-korupsi, tapi secara diam-diam maupun terbuka masih konsisten memperjuangkan nilai-nilai fundamentalistik ${ }^{8}$

Warna ideologis PKS jauh lebih radikal, sekalipun pada tingkat praksis sangat idealis. ${ }^{9}$ PKS menampakkan dukungan yang serius terhadap Perda bernuansa syariah. ${ }^{10}$ Platform PKS tidak mengingkari Pancasila sebagai dasar negara, namun pikiran dan tindakan para kadernya condong mendukung gagasan khiläfah islämiyyah atau penerapan syariat Islam. Simbol-simbol kebangsaan juga jarang ditemukan di kantor-kantor PKS. Perbedaan antara sikap politik partai

\footnotetext{
${ }^{5}$ Keynote Speech Kepala BNPT pada kegiatan "Dialog Publik Radikalisme, Terorisme dan Deradikalisasi Paham Radikal”, diselenggarakan MUI Jawa Tengah, 3 Desember 2011.

${ }^{6}$ Hizbut Tahrir Indonesia, Selamatkan Indonesia dengan Syariah, (Jakarta: HTI Press, 2006).

7Sadanand Dhume, "Radical March on Indonesia's Future," dalam Far Eastern Economic Review, vol. 168, Mei 2005, sebagaimana dikutip Burhanuddin Muhtadi, Dilema PKS Suara dan Syariah, Oakarta: KPG, 2012), h. 8-9.

${ }^{8}$ Andrew Steele, "The Decline of Political Islam in Indonesia," dalam Asia Times Online Ltd., seperti dikutip Burhanuddin Muhtadi, Dilema PKS..., h. 9.

9Joko J. Prihatmoko, Pemilu 2004 dan Konsolidasi Demokrasi, (Semarang: LP2I Semarang, 2004), h. 128-129.

${ }^{10}$ Abdurrahman Wahid (ed.), Ilusi Negara Islam: Ekpansi Gerakan Islam Transnasional di Indonesia, (Jakarta: Wahid Institut, 2009), h. 138.
} 
dengan sikap politik kader PKS ini menunjukkan adanya agenda tersembunyi atau taqiyyah ${ }^{11}$ politik, yakni berbeda antara hati dan kata yang terucap. Simbolsimbol kebangsaan jarang ditemukan di kantor-kantor PKS. Pandangan PKS tentang Pancasila masih “lonjong”.

Berdasarkan bukti-bukti di atas, hipotesis kajian ini adalah PKS masih menyimpan agenda mengganti dasar negara Indonesia dengan dasar lain. Pandangan PKS tentang Pancasila masih lonjong. Mereka belum sepenuhnya menerima Pancasila sebagai payung kebangsaan bersama (common denominator/ mizallatal-ummah).

Berdasar latar belakang di atas, maka rumusan masalah artikel ini adalah bagaimana pandangan PKS terhadap Pancasila sebagai dasar negara. Tujuan kajian ini adalah untuk menganalisis sikap dan pandangan PKS terhadap Pancasila sebagai dasar negara. Dengan penelitian ini diharapkan dapat memperkaya kajian relasi Pancasila dan Islam (khususnya partai politik Islam) dalam konteks kekinian. Di samping itu, penelitian ini diharapkan dapat menjadi langkah antisipasi dalam menjaga Pancasila dari rongrongan ideologi lain.

Artikel ini merupakan penelitian kualitatif. Data digali melalui wawancara dengan kader PKS dan studi dokumen. Studi dokumen diarahkan untuk menguji konsistensi ideologi PKS dalam platform partai dengan tulisan-tulisan yang pernah dipublikasikan kader PKS, menyangkut Pancasila dan cita-cita negara Islam. Data yang telah terkumpul selanjutnya dianalisis secara deskriptif.

\section{B. Islam dan Pancasila}

Pada umumnya publik menduga bahwa diskusi tentang dasar negara pada awal kemerdekaan sudah tuntas. Seluruh komponen bangsa dianggap sudah sepakat dengan Pancasila dan sudah tidak ada lagi masalah Pancasila sebagai dasar negara. Faktanya hingga sekarang, sebagian umat Islam masih menginginkan ideologi lain di luar Pancasila. Hubungan Islam dan Pancasila telah menjadi dilema dan seolah menjadi proyek yang tidak pernah selesai.

Dasar negara bagi setiap bangsa memiliki makna penting. Ia merupakan cerminan dari falsafah hidup suatu bangsa dan ikatan suci yang menyatukan

\footnotetext{
${ }^{11}$ Taqiyyah adalah doktrin mazhab Syi'ah yang artinya menjaga diri dengan menampakkan sesuatu yang berlawanan dengan apa yang ada dalam hati. Ahlul Bait Indonesia (ABI), Buku Putih Mazhab Syi'ah: Menurut Para Ulamanya yang Muktabar, (Jakarta: DPP ABI, 2012), h. 80-81.
} 
keragaman agama, budaya, suku dan sebagainya. Ketika hendak membangun Indonesia, terjadi perdebatan sengit tentang apa dasar negara yang tepat bagi bangsa yang penduduknya mayoritas Islam ini. Proses pencarian suatu dasar negara yang dapat diterima oleh seluruh rakyat Indonesia yang beragam agama, etnis dan golongan tidaklah mudah. Lebih-lebih ketika setiap golongan merasa bahwa dasar negara terbaik adalah dasar negara yang bersumber dari falsafah hidup dan agama mereka.

Bahan-bahan pemikiran tentang dasar negara Indonesia sudah dipersiapkan sejak lama. Setidaknya sejak dekade 1920-an, pelbagai kreativitas intelektual mulai digagas sebagai usaha mensintesiskan aneka ideologi yang sesuai dengan masyarakat dan bangsa Indonesia. ${ }^{12}$ Bahkan penggalian dasar negara itu tidak berhenti pada zaman gelap penjajahan, melainkan menembus era kejayaan Nusantara. ${ }^{13}$

Secara formal, rumusan dasar negara baru dikemukakan dan diperdebatkan dalam sidang BPUPKI (Badan Penyelidik Usaha-usaha Persiapan Kemerdekaan Indonesia atau Dokuritsu Zyunbi Tyoosakai). BPUPKI dibentuk pemerintah Jepang pada 9 April 1945 sebagai realisasi janji mereka untuk memberikan kemerdekaan kepada Indonesia. Anggotanya berjumlah 68 orang dan yang betul-betul dapat dianggap mewakili kelompok Islam hanya 15 orang, selebihnya adalah golongan nasionalis dan golongan-golongan agama lain di Indonesia. ${ }^{14}$

Suasana tegang dan panas menghiasasi perdebatan tentang dasar negara dalam sidang-sidang BPUPKI. Setiap golongan merasa mempertaruhkan keyakinannya demi Indonesia yang dicita-citakan. Setidaknya ada dua faksi yang mengusulkan dasar negara saat itu. Pertama, usulan dasar negara Islam yang dibela oleh ahli-ahli agama yang bertujuan untuk mendirikan negara Islam Indonesia (Ki Bagus Hadikusumo, Abdul Kahar Muzakkir, KH. Abdul Wahid Hasjim dan lain-lain). Kedua, aliran pemisahan negara dan agama yang diusulkan oleh kelompok nasionalis (Soekarno, M. Hatta, Soepomo dan kawan-kawan).15

\footnotetext{
${ }^{12}$ Yudi Latif, Negara Paripurna: Historisitas, Rasionalitas dan Aktualitas Pancasila, (Jakarta: Gramedia Pustaka Utama, 2011), h. 5.

13Yudi Latif, Negara Paripurna..., h. 4.

${ }^{14}$ Ahmad Syafii Maarif, Islam dan Masalah Kenegaraan: Studi tentang Percaturan dalam Konstituante, (Jakarta: LP3ES, 1985), h. 102.

${ }^{15}$ Ahmad Syafii Maarif, Islam dan Masalah Kenegaraan..., h. 104. Bandingkan dengan Endang Saifuddin Anshari yang menggunakan sebutan "nasionalis-Islamisis" dan "nasionalis-sekularis" untuk
} 
Soal dasar negara telah membuat para pendiri republik dalam situasi sulit. Jika mereka gagal merumuskan dasar negara, ada dua resiko yang sama-sama tidak menguntungkan: Indonesia batal diproklamasikan (berarti tetap sebagai negara jajahan) atau Indonesia menjadi negara yang terpecah-pecah. Pada akhirnya, kompromi politik dalam bentuk Piagam Jakarta terjadi pada 22 Juni 1945. Piagam Jakarta merupakan preambule bagi konstitusi, di dalamnya terdapat Pancasila sebagai dasar negara dimana sila pertama berbunyi: "Ketuhanan dengan kewajiban menjalankan syariat Islam bagi pemeluk-pemeluknya."16

Seluruh rakyat Indonesia menyambut bangga dan antusias kemerdekaan Indonesia yang diproklamasikan pada 17 Agustus 1945. Tetapi kelompok nonIslam merasa ada yang tidak beres dalam dasar negara Pancasila, terutama anak kalimat: "... dengan kewajiban menjalankan syariat Islam bagi pemeluk-pemeluknya." Tokoh agama Kristen, Latuharhary misalnya, memberikan tanggapan:

"... akibatnya akan sangat besar sekali, umpamanya terhadap agama lain. Maka dari itu, saya harap supaya dalam hukum dasar, ... tidak boleh diadakan benih-benih atau kemungkinan yang dapat diartikan dalam rupa-rupa macam...."17

Keberatan juga datang dari Wongsonegoro (tokoh Jawa) dan Hoesein Djayadiningrat (Kepala Urusan Agama Pemerintah Jepang) yang mengkhawatirkan munculnya fanatisme agama akibat pelaksanaan hukum Islam yang dipaksakan. ${ }^{18}$ Jika tujuh kata tidak dihapus dalam konstitusi, menurut Hatta, kelompok Kristen dan Katolik dari Timur Indonesia akan memisahkan diri dari Negara Kesatuan Republik Indonesia. ${ }^{19}$

Setelah melewati masa-masa kritis, maka pada tanggal 18 Agustus 1945, wakil-wakil dari umat Islam akhirnya menyetujui usul penghapusan anak kalimat tersebut dari Pancasila dan batang tubuh UUD 1945, dengan tambahan atribut yang sangat kunci, hingga menjadi: "Ketuhanan Yang Maha Esa."20

membedakan dua faksi yang sedang memperjuangkan dasar negara. Endang Saifudin Anshari, Piagam Jakarta 22 Juni 1945, (Jakarta: 1983), h. 46.

${ }^{16}$ Ahmad Syafii Maarif, Islam dan Masalah Kenegaraan..., h. 107-108.

${ }^{17}$ Yudi Latif, Negara Paripurna..., h. 26.

${ }^{18}$ Arskal Salim, Challenging The Secular State: The Islamization of Law in Modern Indonesia, (USA: University of Hawai'i Press, 2008), h. 64-65.

${ }^{19}$ Arskal Salim, Challenging The Secular State: ..., h. 69.

${ }^{20}$ Ahmad Syafii Maarif, Islam dan Masalah Kenegaraan..., h. 109. 
Perubahan di atas dipandang oleh sebagian orang sebagai kekalahan politik umat Islam. Tetapi pada 1978, Alamsjah Ratu Perwiranegara, Menteri Agama saat itu menafsirkan peristiwa tanggal 18 Agustus 1945 sebagai hadiah umat Islam kepada bangsa dan kemerdekaan Indonesia, demi menjaga persatuan. Pernyataan Alamsjah ini dapat diartikan sebagai usaha untuk meyakinkan banyak pihak bahwa loyalitas umat Islam kepada Pancasila tidak perlu dipertanyakan lagi. ${ }^{21}$

Perdebatan tentang dasar negara rupanya tidak berhenti setelah kemerdekaan Indonesia. Perdebatan tentang dasar negara kembali muncul pada sidang Majelis Konstituante pada tahun 1957, setelah Indonesia mengadakan Pemilu pertama pada 1955 dimana partai-partai Islam memperoleh kurang dari $45 \%$ suara. Pada saat itu, terdapat tiga usulan dasar negara, yaitu: Pancasila, Islam dan Sosial-Ekonomi. Usul yang terakhir hanya didukung oleh partai kecil, yaitu Partai Buruh dan Partai Murba. Selebihnya, perdebatan mengerucut pada dua kelompok, yaitu pendukung Islam dan pendukung Pancasila. Perdebatan di Majelis Konstituante berjalan alot dan kritis. Masing-masing pihak berusaha meyakinkan ideologi yang diusung sebagai ideologi terbaik yang patut menjadi dasar negara. Sidang Majelis Konstituante tidak menghasilkan keputusan apapun. Maka pada tanggal 5 Juli 1959, Presiden Soekarno dengan sokongan penuh pihak militer mengeluarkan dekrit untuk kembali kepada UUD 1945 dan sekaligus membubarkan Majelis Konstituante yang dipilih rakyat saat Pemilu 1955.22

Dengan berlakunya kembali UUD 1945, maka dasar negara Islam yang diusulkan oleh partai-partai Islam dengan sendirinya tertolak melalui dekrit 5 Juli 1959, dan bukan melalui jalan musyawarah yang demokratis. Pada akhirnya, Pancasilalah yang menjadi dasar negara Indonesia hingga kini, sekalipun kata Pancasila tidak pernah disebut dalam pembukaan UUD 1945.

Paparan di atas menunjukkan betapa tidak mudah merumuskan Pancasila sebagai dasar. Bagi generasi yang tidak mengalami masa-masa sulit perumusan Pancasila, mereka hendaknya belajar dari sejarah dan tidak menganggap enteng Pancasila. Oleh karena itu, setelah Pancasila melewati tiga fase sejarah (fase pembuahan, fase perumusan, fase pengesahan) sebagaimana pendapat Yudi Latif,, ${ }^{23}$ maka untuk keperluan masa kini dan masa datang, diperlukan fase

\footnotetext{
${ }^{21}$ Ahmad Syafii Maarif, Islam dan Masalah Kenegaraan..., h. 109.

${ }^{22}$ Ahmad Syafii Maarif, Islam dan Masalah Kenegaraan..., h. 176.

23Yudi Latif, Negara Paripurna....
} 
keempat, yaitu fase pemeliharaan dan perlindungan. Fase ini sangat penting agar bangunan Negara Kesatuan Republik Indonesia (NKRI) dengan Pancasila sebagai dasar negara tetap terpelihara dan terlindungi keberadaannya, di tengah berbagai ancaman ideologi yang beraneka ragam, baik dari dalam maupun dari luar.

Secara teoritik, di kalangan umat Islam terdapat tiga aliran tentang hubungan antara Islam dan ketatanegaraan (politik). ${ }^{24}$ Pertama, Islam mengatur segala aspek kehidupan manusia. Ia tidak sekedar agama, tapi juga politik. Oleh karenanya, mendirikan negara menjadi salah satu ajaran dalam Islam yang harus dilaksanakan. Penganut aliran ini antara lain adalah Hassan al-Banna, Sayyid Quthb, Rasyid Ridha dan Abu al-A'la al-Maududi. Kedua, Islam adalah agama yang tidak ada hubungaannya dengan aspek kenegaraan. Agama harus dipisahkan dengan urusan politik. Agama tidak memerintahkan pemeluknya untuk mendirikan negara. Pandangan sekularis ini diwakili oleh 'Ali 'Abd al-Raziq dan Thaha Husein. Ketiga, aliran yang menolak pandangan dua kelompok pemikiran sebelumnya, dengan mengajukan tesis baru bahwa di dalam Islam memang tidak terdapat ajaran tentang politik dan kenegaraan, tetapi terdapat tata nilai dan etika bagi kehidupan bernegara.

Pendapat di atas, agak berbeda dari pandangan Din Syamsuddin. Menurutnya, sejauh menyangkut orientasi politik, setidaknya ada tiga pemikiran dan gerakan mainstream umat Islam. ${ }^{25}$ Pertama, arus formalistik yang menginginkan bentuk-bentuk formal dalam politik Islam. Mereka menginginkan dasar negara Islam, simbol politik Islam dan segala aspek kehidupan harus berdasarkan syariat Islam. Kedua, arus substantivistik yang lebih menekankan tuntutan manifestasi substansial nilai-nilai Islam dalam aktivitas politik. Dalam konteks dasar negara misalnya, sebutan, bentuk, atau simbol boleh beragam, tetapi yang pasti isinya adalah nilai dan ajaran Islam. Ketiga, arus fundamentalisme yakni arus yang berada di luar dua arus sebelumnya yang dianggap telah gagal menunjukkan Islam sebagai keseimbangan-tanding dalam merespons sistem politik yang ada.

Pada sisi lain, menurut Bahtiar Effendi, Islam politik di Indonesia juga dapat ditinjau dari teori trikotomi, yakni fundamentalis, reformis dan akomodasionisme. ${ }^{26}$ Kelompok fundamentalisme mendukung jenis penafsiran Islam yang

\footnotetext{
${ }^{24}$ Munawir Sjadzali, Islam dan Tata Negara: Ajaran, Sejarah dan Pemikiran, Uakarta: UI Press, 1993), h. 1-2.

25 M. Din Syamsuddin, Islam dan Politik di Era Orde Baru, (Jakarta: Logos, 2001), h. 151.

${ }^{26}$ Bahtiar Effendy, Islam dan Negara: Transformasi Pemikiran dan Praktik Politik Islam di Indonesia, (Jakarta: Paramadina, 1998), h. 41-42.
} 
kaku dan literal, menentang pemikiran sekular, dan menekankan keutamaan Islam atas politik. Kelompok reformis juga menekankan keutamaan atas politik, tetapi dibandingkan dengan kelompok fundamentalis, mereka jauh lebih kompromistis dan mau diajak kerjasama dengan kelompok sekuler atas landasan yang disepakati. Kelompok akomodasionis memberi penghargaan yang tinggi kepada kerangka persatuan yang diberikan Islam, tetapi mereka berpegang pada pandangan bahwa kepentingan-kepentingan sosial dan ekonomi harus mendapat prioritas utama oleh organisasi-organisasi Islam.

Teori trikotomi di atas jika diterapkan dalam konteks dasar negara, akan ditemukan dua pola. Pertama, kelompok Islam murni (fundamentalis) yang hanya mengakui dasar Islam dan tidak mau yang lain. Kedua, kelompok Islam moderat atau kelompok Islam nasionalis yang memberi ruang ideologi lain asal substansi di dalamnya terdapat nilai-nilai Islam.

Dengan kata lain, dalam pandangan Salim, terdapat tiga jenis hubungan antara Islam dan negara. ${ }^{27}$ Pertama, tipe integrasi (integration) yaitu Islam dan negara menyatu. Kedua, tipe diferensiasi (differentiation) dimana agama dan negara saling membutuhkan dan bekerjasama. Ketiga, pemisahan (separation) antara agama dan negara yang mengarah pada model negara sekuler. Dari tiga tipe ini, Indonesia berada pada jenis yang kedua.

Menjadi Indonesia yang berdasarkan Pancasila adalah pilihan logis umat Islam. Jika penerapan dasar negara Islam dipaksakan, boleh jadi nasib Indonesia belum tentu seperti sekarang. Mungkin Negara Kesatuan Republik Indonesia (NKRI) akan bubar. Atau daerah-daerah Kristiani atau Hindu akan memisahkan diri. ${ }^{28}$ Konon, masih banyak umat Islam yang meragukan, apakah ancaman ini mitos atau realitas.

\section{PKS dan Pancasila}

Samuel P. Huntington dalam buku The Clash of Civilization menyatakan bahwa akan terjadi benturan antar peradaban, khususnya antara Islam dan Barat. Barat diidentifikasi memiliki karakter yang unik, yakni individualisme dan demokrasi. Karakter yang demikian tidak dimiliki oleh masyarakat lain, termasuk dunia Islam. Oleh karena itu, demokrasi tidak bisa tumbuh di dunia Islam karena

\footnotetext{
${ }^{27}$ Arskal Salim, Challenging The Secular State..., h. 22.

${ }^{28}$ Dawam Rahardjo, "Kata Pengantar" dalam Budhy Munawar-Rachman Reorientasi Pembaruan Islam: Sekularisme, Liberalisme dan Pluralisme, Paradigma Baru Islam di Indonesia, Oakarta: Paramadina, 2010), h. xxix.
} 
karakter umat Islam yang tidak mendukungnya. Bahkan secara provokatif, Huntington menegaskan bahwa "persoalan bagi masyarakat Barat bukanlah fundamentalisme Islam tapi Islam itu sendiri."29

Salah satu karakter ketidakmungkinan demokrasi tumbuh di negara Islam karena konsep kesatuan agama dan negara. Konsep ini dianggap menghalangi demokrasi karena bertentangan dengan semangat sekularisme. Secara konseptual, sekularisme adalah paham tentang pemisahan antara agama dan politik (atau negara). Tujuannya untuk meniadakan intervensi agama terhadap negara dan sebaliknya. Agama adalah urusan pribadi, negara tidak ikut campur di dalamnya. Namun demikian, sekularisme itu tidak anti agama. Dalam negara sekuler, kebebasan beragama betul-betul dijamin dan dilindungi di negara-negara sekuler. ${ }^{30}$

Belakangan klaim ini makin ditinggalkan. Faktanya di negara yang paling demokratis sekalipun, pemisahan negara dan agama tidak pernah benar-benar terjadi. Bahkan, agama justru menjadi kekuatan inspiratif dalam negara. Inggris atau Jerman adalah negara demokratis tapi partai berbasis agama juga berkembang. ${ }^{31}$

Dalam konteks di atas, Indonesia sebagai negara yang bukan negara agama memberikan pilihan-pilihan politik yang luas bagi rakyatnya. Sejak masa lalu hingga era sekarang, partai politik yang berlandaskan pada agama tetap tumbuh. Jadi, apa yang terjadi di Indonesia (di mana banyak partai agama yang muncul) adalah sesuatu yang normal saja, sebagaimana yang terjadi di Inggris, Jerman atau Belanda.

Politik dan partai politik telah menjadi bagian dari kesadaran umat Islam Indonesia sejak awal masa kemerdekaan. Oleh karena itu, dari Pemilu pertama (tahun 1955) hingga sekarang, umat Islam selalu berpartisipasi aktif dalam kegiatan demokrasi dengan mendirikan partai politik. Dalam hal mendirikan partai politik dan menyalurkan aspirasi politik, umat Islam memiliki pandangan yang beragam. Sebagian menganggap mencoblos partai Islam adalah wajib (formal). Yang lain berprinsip parpol hanyalah sarana dan tidak harus berlandas-

\footnotetext{
${ }^{29}$ Sebagaimana dikutip Saiful Mujani, Muslim Demokrat: Islam, Budaya Demokrasi dan Partisipasi Politik di Indonesia Pasca-Orde Baru, (Jakarta: Gramedia, 2007), h. 14.

${ }^{30}$ Budhy Munawar-Rachman, Reorientasi Pembaruan Islam: Sekularisme, Liberalisme dan Pluralisme, Paradigma Baru Islam di Indonesia, (Jakarta: Paramadina, 2010), h. 234-235.

31Saidiman Ahmad, "Peran Ganda Politik Demokratis Masyumi Masa Orde Lama," dalam Jurnal Ulumul Qur'an, No.01/XXI/2012, h. 27.
} 
kan Islam (substansial). Yang terakhir, umat Islam tidak peduli terhadap partai politik Islam (sekuler). Bagi mereka, semua partai adalah sama. ${ }^{32}$

Kelahiran Partai Keadilan Sejahtera (PKS) dibidani oleh Jama'ah Tarbiyah pada 9 Agustus 1998. Pada awalnya, partai ini bernama Partai Keadilan (PK). Perubahan dilakukan pada 20 Juli $2003^{33}$ setelah PK gagal memenuhi electoral threshold (2\%) pada Pemilu 1999 dan hanya memperoleh 1,3\% suara. ${ }^{34}$

Kelahiran PKS dapat disederhanakan ke dalam tiga tahap. ${ }^{35}$ Tahap pertama adalah fase dakwah kampus. Para aktivis yang kebanyakan berusia muda bergerak dari dalam kampus (umumnya universitas umum) dan dalam skala terbatas di sekolah-sekolah. Mereka mendirikan dan mengelola pengajian yang diwadahi dalam lembaga Lembaga Dakwah Kampus (LDK). Di sekolah-sekolah, mereka mendirikan lembaga yang disebut Rohani Islam (ROHIS). Kegiatan yang dilakukan dua lembaga tersebut adalah sama, yakni memberikan pemahaman dasar-dasar Islam dengan penekanan pada penanaman ghirah keislaman.

Tahap kedua adalah pelembagaan gerakan mahasiswa. Lambat laun, LDK semakin berkembang di kampus-kampus umum. Masjid-masjid kampus menjadi pusat kegiatan dakwah, dan dihadiri banyak mahasiswa untuk ikut serta dalam lingkaran kecil kajian agama (halaqah). Pada pertemuan yang ke-10 Forum Silaturrahmi Lembaga Dakwah Kampus (FSLDK), beberapa aktivis LDK mengumumkan pembentukan Kesatuan Aksi Mahasiswa Muslim Indonesia (KAMMI). ${ }^{36}$

Tahap ketiga adalah gerakan politik. Inisiatif mendirikan partai politik sesaat setelah Presiden Soeharto lengser tahun 1998 datang dari aktivis KAMMI yang didukung pula oleh aktivis dakwah kampus. Mereka percaya bahwa berpartisipasi dalam sistem demokrasi akan mendatangkan banyak keuntungan. ${ }^{37}$

Selain aktivis dakwah tarbiyah, ${ }^{38}$ PKS juga mendapatkan dukungan ideologis dari alumni LIPIA, Saudi Arabia dan Timur Tengah pada umumnya. Bukti-bukti

\footnotetext{
${ }^{32}$ Bandingkan M. Din Syamsuddin, Islam dan Politik Era Orde Baru, h. 151 dan seterusnya.

${ }^{33}$ Yon Machmudi, "Islamising Indonesia: The Rise of Jemaah Tarbiyah and The Prosperous Justice Party (PKS)", Tesis, (Australia: ANU Epress, 2006), h. 2.

${ }^{34}$ Aris Ananta, Evi NA, Leo Suryadinata, Emerging Democracy in Indonesia, (Singapore: Institute of Southeast Asian Studies, 2005), h. 24.

${ }^{35}$ Burhanuddin Muhtadi, Dilema PKS: Suara dan Syariah, (Jakarta: KPG, 2012), h. 32 dan seterusnya.

36Burhanuddin Muhtadi, Dilema PKS..., h. 43.

${ }^{37}$ Burhanuddin Muhtadi, Dilema PKS..., h. 44.

${ }^{38}$ Baca 'Ali Said Damanik, Fenomena Partai Keadilan: Transformasi 20 Tahun Gerakan Tarbiyah di Indonesia, (Jakarta: Teraju, 2002).
} 
demikian sangat gampang dilihat, antara lain misalnya, dua orang dari empat presiden PKS adalah alumni Timur Tengah, yaitu Hidayat Nurwahid dan Lutfi Hasan Ishaq. Dua presiden yang lain adalah alumni dakwah kampus, yaitu Nur Mahmudi Ismail dan Tiffatul Sembiring. Kini PKS dipimpin oleh Anis Matta (LIPIA Jakarta).

Basis massa PKS kebanyakan tinggal di kota, berpendidikan tinggi, pegawai kantoran, dan berkultur Islam modernis. Dengan demikian, konstituen PKS memiliki kesamaan dengan ormas Muhammadiyah dari sisi kultur keagamaan dan sama dengan kultur pendukung PAN sehingga tidak mengherankan apabila anggota Muhammadiyah dan konstituen PAN adalah kelompok yang sangat potensial direbut oleh PKS. ${ }^{39}$ Ideologi Islam yang dibawa adalah Islam ala Ikhwan al-Muslimin Mesir, yang cenderung dekat dengan paham Wahabiyah.

Visi Indonesia yang dicita-citakan adalah PKS adalah terwujudnya masyarakat madani yang adil, sejahtera dan bermartabat. Misi bidang politik yang diemban oleh PKS adalah berkaitan dengan bentuk negara. Sebagai wujud dari tanggung jawab kaum Muslim terhadap rumah besarnya yang bernama Indonesia, dan panggilan dakwah yang menjadi rahmat bagi semesta alam, PKS bahu-membahu bersama entitas politik lainnya untuk mengisi pembangunan menuju Indonesia yang maju, kuat, sejahtera dan bermartabat sesuai dengan citacita universal, yakni Negara Kesatuan Republik Indonesia yang adil dan makmur di bawah lindungan Allah. ${ }^{40}$

Secara pemikiran politik, PKS menolak pemisahan agama dan negara (sekularisme) di Indonesia. Sekularisme dianggap tidak relevan, karena Indonesia adalah negara yang mengakui tauhid, Ketuhanan Yang Maha Esa. Jadi, menurut PKS, Indonesia adalah NKRI yang Berketuhanan Yang Maha Esa.41 Secara formal kepartaian, PKS berusaha menyesuaikan diri dengan norma kehidupan tata negara, tetapi simbol-simbol nasionalisme (Pancasila, UUD 1945) tidak tampak dalam platform.

Mengapa simbol-simbol kebangsaan tidak ada, karena PKS berasaskan Islam. Visi awal pendirian PKS adalah berusaha menjadikan Islam sebagai solusi bagi

\footnotetext{
${ }^{39}$ M. Imdadun Rahmat, Ideologi Politik PKS: Dari Masjid Kampus ke Gedung Parlemen, (Yogyakarta: LKiS, 2008), h. 42.

${ }^{40}$ MPP PKS, Platform Kebijakan Pembangunan Partai Keadilan Sejahtera, (Jakarta, 2007), h. vi.

${ }^{41} \mathrm{MPP}$ PKS, Platform Kebijakan..., h. vi.
} 
kehidupan kenegaraan.42 Dalam konteks ini, dapat dibaca bahwa perjuangan PKS pada level negara adalah penerapan syariat Islam. Penerapan syariat Islam yang bagaimana dan kapan, itulah yang hingga hari ini belum terumuskan secara definitif oleh kader PKS.

Dari sisi kader, Pancasila sebagai dasar negara disikapi secara beragam. Sebagian merasa hubungan PKS dan Pancasila sudah selesai, sebagian lain tampak masih menyimpan cita-cita untuk mendirikan negara Islam. Seorang kader PKS Jawa Tengah, Suharsono, menyatakan bahwa PKS tidak memiliki agenda mendirikan Negara Islam atau khilāfah islāmiyyah. Menurutnya: 43

"PKS memandang bahwa Pancasila merupakan dasar dan ideologi negara. Hal itu merupakan harga mati. PKS tidak akan merubah dengan dasar lain, selama nilai-nilai yang ada (dalam Pancasila) merupakan cerminan dari budaya dan keinginan masyarakat. Oleh karena itu, (Pancasila) harus dilestarikan dan dijunjung tinggi...."

Ketika ditanyakan, adakah di kalangan kader PKS yang tidak puas dengan Pancasila dan ingin menggantinya dengan ideologi agama, Suharsono menjawab:

"Kalau (di) PKS tidak ada (kader yang mengusulkan seperti itu. Kita menyampaikan (kepada para kader) bahwa asas Pancasila itu (merupakan) nilai perjuangan kita. Demi dasar negara ini, mestinya semangat itu bisa utuh dan bahkan dapat ditingkatkan. Selama ini, kita melihat Pancasila hanya semacam simbol, belum mampu nilai Pancasila termanifestasi dalam seluruh aspek kehidupan rakyat."

Ketika didesak dengan pertanyaan apakah partai masih menyimpan cita-cita untuk menghidupkan Piagam Jakarta, Suharsono menjawab:

"Ya, semangat kita memang apa yang ada sekarang (Pancasila) kita optimalkan, tidak berandai-andai. Selama kemanfaatannya (Pancasila) besar kepada masyarakat, ini yang ditonjolkan. Kita tidak sekedar berpikir simbolis, tidak juga mengedepankan formalitas, namun yang dikedepankan adalah kerja. Bagaimana PKS ini bekerja membantu masyarakat, membebaskan permasalahan bangsa, menyejahterakan rakyat, dan mengedepankan nilai-nilai keadilan. PKS pingin menjadi contoh itu."

Bagaimana mendudukkan posisi yang tepat, antara cita-cita keislaman (mendirikan negara Islam sebagai wujud Islam yang käffah) dengan cita-cita kebangsaan (Pancasila sebagai dasar negara)? Suharsono menegaskan:

\footnotetext{
${ }^{42}$ Aris Ananta, Evi NA, Leo Suryadinata, Emerging Democracy..., h. 24.

43Wawancara, 30 Juli 2012.
} 
"Karena kita tidak ada keinginan (seperti) di atas (mendirikan negara Islam), (maka) Islam yang kāffah itu tidak harus berwujud simbol negara Islam. Tapi bagaimana negara bisa mengaplikasikan nilai-nilai Islam itu secara menyeluruh dalam aspek kehidupan. Yang terpenting di sini adalah nilai-nilai Islam (value) itu yang lebih kita utamakan, bukan sekedar simbol. Intinya, Islam käffah itu tidak harus berwujud negara Islam."

Jawaban Suharsono di atas bila dibandingkan dengan kader PKS yang lain saling bertentangan. Jawaban itu terkesan bersifat normatif. Padahal, kaderkader PKS dikenal militan dalam pengamalan Islam. Menurut Imdadun Rakhmat, PKS memiliki berbagai agenda dakwah, antara lain menegakkan syariat Islam, menegakkan sistem pemerintahan Islam dan khilāfah islāmiyyah. ${ }^{4}$

Sikap-sikap individual kader PKS sangat memimpikan terwujudnya khilāfah islāmiyyah. Abu Ridho, seorang ideolog PKS misalnya, mengatakan bahwa agar kaum Muslim mampu merealisasikan tujuan-tujuan sosial dan politik (siyāsah) Islam sehingga memiliki tatanan mandiri yang terbebas dari pengaruh tatanan lainnya, diperlukan tegaknya sistem khiläfah yang berlandaskan manhaj kenabian. ${ }^{45}$ Abu Ridho secara gamblang menjelaskan bahwa:

"Bagi partai Islam, ideologi Islam adalah pondasi bagi seluruh aktivitas dan struktur organisasi. Dalam konteks ini, bidang kaderisasi (PKS) bertanggung jawab menanamkan ideologi Islam kepada semua kader...." 46

Latar belakang Ketua Majelis Syuro PKS, Hilmi Aminuddin juga mendorong publik berspekulasi bahwa PKS tidak dapat dilepaskan dari cita-cita mendirikan Negara Islam. Hilmi adalah anak Danu Muhammad Hasan yang merupakan tokoh NII di Jawa Barat. Meski Hilmi sudah kerap membantahnya, kaitan Hilmi dengan NII akan menjadi beban sejarah yang sulit dihilangkan. Potensi PKS untuk tidak setia kepada Pancasila dianggap sangat tinggi.

Meski banyak kader PKS menolak dikaitkan dengan cita-cita iqāmat aldawlah al-islāmiyyah, bagi mereka, Pancasila bukanlah harga mati. Artinya, masih mungkin Pancasila diganti dengan ideologi lain. Pandangan ini melahirkan sikap mengambang menyangkut penerimaan Pancasila sebagai ideologi negara. ${ }^{47}$ Karena sikap ini, dan dominasi nilai Islam yang dikandungnya mendorong publik terus bertanya apakah PKS akan mendirikan Negara Islam Indonesia?

\footnotetext{
${ }^{44}$ M. Imdadun Rahmat, Ideologi Politik PKS..., h. 55-58.

${ }^{45} \mathrm{Abu}$ Ridho, Saat Dakwah Memasuki Wilayah Politik, (Bandung: Syamil, 2003), h. 26.

46Sebagaimana dikutip Burhanuddin Muhtadi, Dilema PKS..., h. 174.

47M. Imdadun Rahmat, Ideologi Politik PKS..., h. 196-197.
} 
Keraguan publik ini sudah dijawab seorang pemimpin terkemuka PKS:

"Jika substansi sudah cukup mewakili nama (yaitu Negara Islam), formalitas nama Negara Islam tak lagi dibutuhkan... Sebelumnya Indonesia berjalan secara sekuler, sekarang kami ingin menjalankan secara islami. Itulah intinya. Oleh karena itu, PKS tidak berharap muluk-muluk tentang negara Islam atau syariat Islam." 48

Jawaban di atas tidak memuaskan karena asas, visi dan misi partai PKS tidak mendukungnya. Bahkan, kader PKS meyakini bahwa implementasi syariah dapat menjadi solusi bagi multikrisis di Indonesia. Implementasi ini harus dilakukan secara damai dan konstitusional (peaceful and constitutional way), bukan dengan kekerasan atau paksaan. ${ }^{49}$ Statemen ini dapat dimaknai bahwa bagi PKS, dasar negara Indonesia adalah proyek yang belum selesai.

Sebagai ideologi bangsa, Pancasila sejatinya dapat menjadi nation ethics (etika berbangsa) yang harus dijunjung oleh semua komponen bangsa. Nation ethics dalam konteks multikulturalisme bangsa harus mencerminkan, meminjam istilah John Rawls, overlapping concensus (kesepakatan yang bertumpukan). Oleh karena itu, tidak ada cara lain yang sudah teruji dalam sejarah Indonesia, kecuali menjadikan Pancasila sebagai common ground dan common platform dimana semua warga berhak ikut serta dalam permainan di dalamnya. Atau, merevitalisasi fungsi Pancasila sebagai public ethics bagi bangsa Indonesia. ${ }^{50}$

\section{Taqiyyah Politik PKS}

Kehadiran PKS merupakan perkembangan positif dari munculnya gerakan Islam baru (new Islamic movement) yang dimotori anak-anak muda jaringan LDK (Lembaga Dakwah Kampus). ${ }^{51}$ Persoalan yang sering menjadi sorotan dalam PKS adalah menyangkut bagaimana partai yang berideologi Islam dan mencanangkan dirinya sebagai partai dakwah ini menempatkan dirinya dalam konteks Indonesia yang menganut prinsip negara bangsa (nation state) dan berdasarkan Pancasila.

Pada dasarnya, Pancasila merupakan konsensus nasional yang memuat nilainilai "kebaikan bersama" sebagai dasar pemersatu suatu negara. Sebagai sebuah

\footnotetext{
48Sebagaimana dikutip Burhanuddin Muhtadi, Dilema PKS..., h. 170.

${ }^{49}$ Yon Machmudi, Islamising Indonesia..., h. 195.

${ }^{50}$ Abu Hapsin, "Peran Tokoh Agama/ Lembaga Keagamaan dalam Menciptakan Kerukunan Kehidupan Keagamaan Yang Harmonis," bahan diskusi pada Halaqah Ulama Peran Lembaga Keagamaan dalam Pelayanan Umat, MUI Jawa Tengah, 21 September 2012.

51 M. Imdadun Rahmat, Ideologi Politik PKS..., h. 189.
} 
konsensus, apakah Pancasila merupakan falsafah negara atau sekedar persetujuan politik, hal demikian bisa jadi debatable. Tetapi, setiap perjanjian (consensus) adalah suci bagi pihak-pihak yang terikat. Kesucian itu setidaknya menuntut dua hal. Pertama, keharusan untuk melaksanakan isi perjanjian. Kedua, larangan untuk mengkhianati isi perjanjian.

Kesucian sebuah kesepakatan itu menjadi bentuk moral tertinggi suatu masyarakat. Kehormatan suatu bangsa — pada masa lalu misalnya — diukur dari apakah bangsa itu setia dengan perjanjian yang disepakati bersama atau tidak. Apabila tidak, maka bangsa tersebut dikucilkan dari pergaulan antar suku. Lebih dari itu, pengkhianat atas suatu kesepakatan dapat melahirkan peperangan yang turun-temurun. Sebuah perjanjian menuntut kejujuran bagi pihak-pihak yang terikat di dalamnya.

Dalam konteks di atas, Pancasila merupakan perjanjian suci bangsa yang menjadi dasar kenegaraan Indonesia. Di dalam perjanjian tersebut, disepakati lima hal pokok (lima sila) yang menjadi payung kebersamaan bangsa (mizalat alummah) yang beragam agama, suku dan budaya. Jadi, kesepakatan itu (yang kemudian disebut Pancasila) dasar-dasar untuk hidup bersama.

Oleh karena Pancasila merupakan kesepakatan bersama para pendiri bangsa, maka penerus bangsa ini harus mengakui bahwa perjanjian itu mengikat seluruh komponen bangsa, apapun agama dan kepercayaannya. Bahwa di dalam perjanjian itu, mungkin ada ketidaksempurnaan —sebagaimana dalam ajaran agama (identik dengan kesempurnaan yang paripurna) — bisa saja terjadi. Tetapi sebagai sebuah kesepakatan, ia tetaplah suci dan tidak boleh dicaci-maki. Kecuali kalau seluruh bangsa menghendaki agar Pancasila diganti dengan ideologi lain.

Sehubungan dengan itu, partai politik memiliki tanggung jawab besar untuk mengawal dan mempertahankan kesepakatan nasional (Pancasila). Apabila ada partai politik yang masih ragu-ragu tentang kesepakatan nasional ini, patut diduga ia masih menyimpan agenda tersembunyi. Hal ini, dapat dipandang sebagai pengkhianatan terhadap perjanjian suci yang telah dibangun oleh para pendiri bangsa. 52

\footnotetext{
${ }^{52}$ Sikap NU tentang hal ini jauh lebih tegas. Bagi NU, orang atau kelompok, baik atas nama agama atau ideologi lain yang menolak Pancasila sebagai ideologi negara dan menolak Mukaddimah UUD 1945 sama dengan membubarkan Negara Republik Indonesia. Karena itu, tindakan mereka dapat digolongkan sebagai bughat (subversive) yang harus dicegah kehadirannya. Baca PBNU, "Negara Menurut Ahlussunnah wal Jama'ah," dalam Materi Musyawarah Nasional Alim Ulama dan Konferensi Besar Nahdlatul Ulama, (Jakarta: PBNU, 2012), h. 193.
} 
Tentu saja, partai politik Islam harus menyadari bahwa Pancasila dan agama adalah dua hal yang berbeda. Pancasila jelas merupakan kreasi manusia, sedangkan agama bersumber dari wahyu Tuhan. Sekalipun Pancasila adalah buatan manusia, bukan berarti ia tidak mengandung kebaikan di dalamnya. Ia memuat nilai-nilai dasar kemanusiaan yang bertumpu pada pengakuan martabat manusia. Menurut Ki Hajar Dewantara, Pancasila khusus sila kedua merupakan prinsip pemberadaban (guiding principles). ${ }^{53}$

Sikap PKS terhadap Pancasila yang mengambang dapat dipandang sebagai praktik taqiyyah politik. Menurut Quraish Shihab, taqiyyah secara bahasa berarti pemeliharaan dan penghindaran ${ }^{54}$ atau penjagaan. ${ }^{55}$ Sumber Syi'ah mendefinisikan taqiyyah sebagai penjagaan seseorang atas dirinya dengan menampakkan sesuatu yang berlawanan dengan apa yang ada dalam hatinya (an yaqiya al-insān nafsahu bimā yaẓharuhu, wa in kanā yaḍmuru khilāfahu).

Quraish Shihab mengonseptualisasikan taqiyyah sebagai meninggalkan sesuatu yang wajib demi memelihara diri atau menghindar dari ancaman atau gangguan. ${ }^{56}$

Menurut Syi'ah, ideologi taqiyyah berasal dari pemahaman atas QS. Ali Imran ayat 28. Menyembunyikan sesuatu karena siasat (tuqat) untuk menyelamatkan diri dipandang sebagai tindakan yang diperbolehkan. Syi'ah adalah paham dalam Islam yang paling sering menggunakan dan mempraktikkan taqiyyah. Bahkan ulama Syi'ah Imamiyyah kenamaan, Syaikh Muhammad Ridha al-Mudzaffar menegaskan taqiyyah adalah ciri khusus Imamiyyah yang tidak dikenal oleh kelompok dan umat yang lain. ${ }^{57}$

Batas-batas yang tidak jelas menyebabkan doktrin taqiyyah tidak mudah dipahami dan diterima. Doktrin ini pula yang menyebabkan mengapa Syi'ah tidak mudah percaya kepada kelompok lain dan kelompok lain juga tidak mudah percaya kepada Syi'ah. Doktrin taqiyyah telah menjadi penutup abadi milik Syi'ah dan membuat mereka selalu misterius dan selalu dicurigai memiliki maksudmaksud tersembunyi (hidden agenda).

\footnotetext{
${ }^{53}$ M. Sastrapratedja, Lima Gagasan yang Dapat Mengubah Indonesia, (Jakarta: Pusat Kajian Filsafat dan Pancasila, 2013), h. 70. h. 199.

${ }^{54}$ Quraish Shihab, Sunnah-Syi'ah Bergandengan Tangan, Mungkinkah? (Jakarta: Lentera Hati, 2007),

${ }^{55}$ Tim ABI, Buku Putih Mazhab Syi'ah..., h. 80.

${ }^{56}$ Quraish Shihab, Sunnah-Syi'ah..., h. 199.

${ }^{57}$ Quraish Shihab, Sunnah-Syi'ah..., h. 199-200.
} 
Dalam pengertian seperti di atas, PKS dipandang telah menyembunyikan maksud hati yang sebenarnya: antara keinginan mengegolkan Islam sebagai ideolog negara dengan setia kepada Pancasila yang telah menjadi komitmen berbangsa. PKS dipandang sebagai kelompok Islam yang setengah-setengah dalam menerima Pancasila. Bagi mereka, Pancasila adalah ideologi sementara yang dapat dan boleh diganti dengan ideologi Islam, jika saatnya tiba.

PKS tidak menolak Pancasila secara terang-terangan, bahkan mereka ikut dan menikmati suasana kebangsaan di bawah payung Pancasila. Namun, mereka masih mencita-citakan Islam sebagai dasar negara di masa yang akan datang. Sikap ini akan menempatkan PKS dalam posisi selalu tertuduh. Dalam jangka panjang, ambivalensi PKS terkait dasar negara ini tidak menguntungkan bagi bangunan NKRI. Dengan sikap ini, sesungguhnya PKS belum menjadi Indonesia secara lahir dan batin.

PKS memang pernah terindikasi sebagai partai Islam garis keras dan kini sudah mulai berubah secara signifikan.58 PKS juga mulai menerima budaya keagamaan orang lain, meskipun menjadi dilema bagi dirinya. ${ }^{59}$ Posisi ini disadari betul oleh PKS sehingga pada Mukernas di Bali pada 2008, sebagian elit partai mendeklarasikan PKS sebagai partai terbuka. Meskipun pilihan ini menimbulkan pro dan kontra di internal partai.60 Pro dan kontra ini mengindikasikan bahwa sebagian besar kader PKS masih menyimpan cita-cita untuk memperjuangkan Islam sebagia dasar negara.

Keinginan untuk mengganti Pancasila dengan ideologi agama, baik yang disuarakan secara terang-terangan (seperti HTI) maupun tersembunyi (seperti PKS) merupakan ancaman terhadap keamanan negara (state security) atau keamanan nasional (national security). Celakanya, ancaman itu tak dapat ditangani oleh negara. Negara tampak kikuk dan gamang dalam menghadapi kelompok Islam yang menghendaki tegaknya syariat Islam.61 Pancasila harus berjuang sendirian untuk menghadapi gempuran ideologi lain.

\footnotetext{
${ }^{58}$ Najwa Shihab dan Yanuar Nugroho, “The Ties That Bind: Law, Islamization and Indonesia's Prosperous Justice Party (PKS)," dalam Australian Journal of Asian Law, Vol. 10 No. 2, Dec, 2008.

${ }^{59}$ Mark Woodward, 'Ali Amin, Inaya Rohmaniyah, Chris Lundry, A New Cultural Path for Indonesia's Islamist PKS, (USA: CSC Arizona State University, 2011), h. 2.

${ }^{60}$ Burhanuddin Muhtadi, Dilema PKS..., h. 227.

${ }^{61}$ As'ad Said 'Ali, "Tinjauan Yuridis terhadap Sarana Hukum sebagai Pengaman Ideologi dan Dasar Negara," dalam upacara penganugerahan gelar Doctor Honoris Causa, (Semarang: Undip, 2012), h. 2-3.
} 
Semestinya, sebagai dasar dan ideologi negara, Pancasila menjadi acuan hidup bersama sebagai bangsa. Pancasila merupakan prinsip dasar (principilia) dan kompromi politik para bapak pendiri bangsa (the founding fathers). Di dalamnya terdapat perjanjian moral yang sangat luhur dari seluruh elemen bangsa. Oleh karena itu, seluruh elemen bangsa harus menjunjung tinggi konsensus ini, meski memiliki agama dan keyakinan yang beragam.

Pada sisi lain, usaha untuk mengganti Pancasila dengan ideologi lain yang dianggap lebih baik akan terus mewarnai perjalanan sejarah bangsa ini. Bagi umat Islam sendiri, seperti yang pernah ditulis M. Natsir, cita-cita umat Islam Indonesia tidak pernah berhenti setelah kemerdekaan Indonesia tercapai. Mereka tetap akan meneruskan perjuangan selama negeri ini belum diatur menurut hukum kenegaraan Islam. ${ }^{62}$

Di masa Indonesia sekarang, barangkali masih banyak umat Islam yang memegangi pandangan Natsir di atas. Sekalipun mungkin dengan alasan yang berbeda, kelompok-kelompok Islam yang masih menyimpan agenda terselubung untuk mengganti dasar negara dengan dasar Islam akan menjadi ancaman nyata keutuhan NKRI.

Islam sejatinya tidak pernah mewajibkan umatnya untuk mendirikan negara Islam. Misi agama Islam adalah menjadi rahmat bagi seluruh alam (wa mā arsalnāka illā raḥmatan li'l-ấlamìn). Logika pesan ini adalah Islam harus dapat tumbuh dan berkembang di manapun tempat. Keberlangsungan Islam tidak bergatung pada dasar dan bentuk negara. Bagi ajaran Islam sendiri, yang paling penting adalah nilai-nilai Islam dapat diamalkan oleh pemeluknya, di manapun mereka berada dan apa pun bentuk negaranya.

Dasar negara suatu bangsa - tempat di mana Islam tumbuh dan berkembang — adalah konsensus rakyatnya. Mereka bebas membentuk dan mendasari negaranya dengan dasar Islam, sekuler atau dasar-dasar lainnya. Oleh karena Indonesia memiliki kultur dan agama yang beragam, maka dasar negara yang dianggap tepat adalah dasar negara yang mampu mengayomi semua agama, etnis dan golongan. Pilihan ini masuk akal, sebab kalau dipaksakan menggunakan dasar negara tertentu sementara ada bagian dari rakyat Indonesia yang tidak meyakininya, hal ini akan menimbulkan "luka" yang tak pernah sembuh.

\footnotetext{
62Bambang Pranowo, "Islam dan Pancasila: Dinamika Politik Islam di Indonesia," dalam Ulumul Qur'an, Vol. III, No. 1 Tahun 1992, h. 7.
} 


\section{E. Kesimpulan}

Pancasila merupakan karya terbaik anak bangsa yang mampu menyatukan seluruh rakyat Indonesia. Keinginan sebagian umat Islam untuk menggantinya dengan dasar agama adalah kesempatan dan peluang untuk terus memperbarui keyakinan dan pemahaman tentang Pancasila. Keinginan tersebut tentu bisa menjadi ancaman apabila bangsa ini abai dengan Pancasila. Peluang dan ancaman itu seolah terus membuat Pancasila mesti tetap terjaga sepanjang masa. Bila Pancasila diam dan membantu, maka akan mudah ditaklukkan dengan dasar negara yang — katanya - lebih baik.

Sikap dan posisi PKS tentang Pancasila dipandang masih dilematis. Asas, visi dan misi PKS tidak sepenuhnya mendukung tegaknya Pancasila sebagai dasar negara. Di dalam diri PKS masih menyimpan cita-cita untuk menegakkan syariat Islam, sekalipun sebagian kader membantahnya. Dilema ini menempatkan Pancasila sebagai bukan keputusan final, dan akan diganti dengan yang lebih baik jika saatnya tiba. Sikap ini menunjukkan bahwa PKS belum menjadi Indonesia lahir dan batin. Keinginan "yang tidak pernah padam" dari sebagian umat Islam untuk memiliki dasar negara Islam merupakan tantangan dan sekaligus peluang menjadikan Pancasila sebagai ideologi yang hidup (living ideology). Oleh karena ia hidup, maka Pancasila bersifat dinamis dan terus-menerus berdialog dengan masyarakat. Dalam posisi seperti ini, Pancasila tidak akan menjadi ideologi yang mati dan statis.[w] 


\section{BIBLIOGRAFI}

Ahmad, Saidiman, "Peran Ganda Politik Demokratis Masyumi Masa Orde Lama," dalam Jurnal Ulumul Qur'an, No. 01/XXI/2012.

'Ali, As'ad Said, "Tinjauan Yuridis terhadap Sarana Hukum sebagai Pengaman Ideologi dan Dasar Negara, " dalam Upacara Penganugerahan Gelar Doctor Honoris Causa, Semarang: Undip, 2012.

Ananta Aris, Evi NA, Leo Suryadinata, Emerging Democracy in Indonesia, Singapore: Institute of Southeast Asian Studies, 2005.

Anshari, Endang Saifudin, Piagam Jakarta 22 Juni 1945, Jakarta: 1983.

Damanik, 'Ali Said, Fenomena Partai Keadilan: Transformasi 20 Tahun Gerakan Tarbiyah di Indonesia, Jakarta: Teraju, 2002.

Effendy, Bahtiar, Islam dan Negara: Transformasi Pemikiran dan Praktik Politik Islam di Indonesia, Jakarta: Paramadina, 1998.

Haidar, M. 'Ali, Nahdatul Ulama dan Islam di Indonesia: Pendekatan Fikih dalam Politik, Jakarta: Gramedia, 1998.

Hapsin, Abu, "Peran Tokoh Agama/Lembaga Keagamaan dalam Menciptakan Kerukunan Kehidupan Keagamaan yang Harmonis, " bahan diskusi pada Halaqah Ulama Peran Lembaga Keagamaan dalam Pelayanan Umat, MUI Jawa Tengah, 21 September 2012.

Harun, Lukman, Muhammadiyah dan Asas Pancasila, Jakarta: Pustaka Panjimas, 1986.

Hizbut Tahrir Indonesia, Selamatkan Indonesia dengan Syariah, Jakarta: HTI Press, 2006.

Latif, Yudi, Negara Paripurna: Historisitas, Rasionalitas dan Aktualitas Pancasila, Jakarta: Gramedia Pustaka Utama, 2011.

Ma'arif, Ahmad Syafi'i, “Saat Pancasila Tak Lagi Bertaji,” Kompas, 10 April 2012.

Ma'arif, Ahmad Syafi'i, Islam dan Masalah Kenegaraan: Studi tentang Percaturan dalam Konstituante, Jakarta: LP3ES, 1985.

Machmudi, Yon, Islamising Indonesia; The Rise of Jemaah Tarbiyah and The Prosperous Justice Party (PKS), thesis, Australia: ANU EPress, 2006. 
Mas'udi, Masdar Farid, “Dulu P-4, kini 4-P,” Kompas, 5 April 2012.

Mbai, Ansyad, "Dialog Publik Radikalisme, Terorisme dan Deradikalisasi Paham Radikal", diselenggarakan MUI Jawa Tengah, 3 Desember 2011.

MPP PKS, Platform Kebijakan Pembangunan Partai Keadilan Sejahtera, Jakarta, 2007.

Muhtadi, Burhanuddin, Dilema PKS: Suara dan Syariah, Jakarta: KPG, 2012.

Mujani, Saiful, Muslim Demokrat: Islam, Budaya Demokrasi dan Partisipasi Politik di Indonesia Pasca-Orde Baru, Jakarta: Gramedia, 2007.

PBNU, "Negara Menurut Ahlussunnah wal Jama'ah," dalam Materi Musyawarah Nasional Alim Ulama dan Konferensi Besar Nahdlatul Ulama, Jakarta: PBNU, 2012.

Pranowo, M. Bambang, "Islam dan Pancasila: Dinamika Politik Islam di Indonesia, " dalam Jurnal Ulumul Qur'an, Vol. III, No. 1, Th. 1992.

Prihatmoko, Joko J., Pemilu 2004 dan Konsolidasi Demokrasi, Semarang: LP2I Semarang, 2004.

Rachman, Budhy Munawar, Reorientasi Pembaruan Islam: Sekularisme, Liberalisme dan Pluralisme, Paradigma Baru Islam di Indonesia, Jakarta: Paramadina, 2010.

Rahardjo, Dawam, "Kata Pengantar" dalam Budhy Munawar-Rachman, Reorientasi Pembaruan Islam: Sekularisme, Liberalisme dan Pluralisme, Paradigma Baru Islam di Indonesia, Jakarta: Paramadina, 2010.

Rahmat, M. Imdadun, Ideologi Politik PKS: Dari Masjid Kampus ke Gedung Parlemen, Yogyakarta: LKiS, 2008.

Ridho, Abu, Saat Dakwah Memasuki Wilayah Politik, Bandung: Syamil, 2003.

Salim, Arskal, Challenging The Secular State: The Islamization of Law in Modern Indonesia, USA: University of Hawai, 2008.

Salim, Arskal dan Azyumardi Azra, "Introduction: The State and Shari'a in the Perspective of Indonesian Legal Politics, " dalam Sharia and Politics in Modern Indonesia, Arskal Salim and Azyumardi Azra (ed.), Singapore: Institute of Southeast Asian Studies, 2003.

Sastrapratedja, M., Lima Gagasan yang Dapat Mengubah Indonesia, Jakarta: Pusat Kajian Filsafat dan Pancasila, 2013.

Shihab, Quraish, Sunnah-Syi'ah Bergandengan Tangan, Mungkinkah?, Jakarta: Lentera Hati, 2007. 
Shihab, Najwa dan Yanuar Nugroho, "The Ties that Bind: Law, Islamisation and Indonesia's Prosperous Justice Party (PKS), " dalam Australian Journal of Asian Law, Vol. 10, No. 2, Dec. 2008.

Sjadzali, Munawir, Islam dan Tata Negara: Ajaran, Sejarah dan Pemikiran, Jakarta: UIPress, 1993.

Syamsuddin, M. Din, Islam dan Politik di Era Orde Baru, Jakarta: Logos, 2001.

Tim Ahlul Bait Indonesia (ABI), Buku Puth Mazhab Syi'ah: Menurut Para Ulamanya yang Muktabar, Jakarta: DPP ABI, 2012.

Wahid, Abdurrahman (ed.), Ilusi Negara Islam: Ekpansi Gerakan Islam Transnasional di Indonesia, Jakarta: Wahid Institut, 2009.

Woodward, Mark, Ali Amin, Inaya Rohmaniyah, Chris Lundry, A New Cultural Path for Indonesia's Islamist PKS, USA: CSC Arizona State University, 2011. 
